\title{
Research on Sludge Treatment and Utilization of Waterworks
}

\author{
Feng $\operatorname{LIN}^{1}$, Shoubin ZHANG ${ }^{2}$, Guoqiang $\mathrm{MA}^{2}$, Liping $\mathrm{QIU}^{2}$, Huajun $\mathrm{SUN}^{3}$ \\ ${ }^{1}$ Rizhao Municipal Drainage Administration, NO.229, Zaozhuang Road.,Rizhao 276800, P.R.China \\ ${ }^{2}$ School of Civil Engineering \& Architecture, University of Jinan, NO.336, Nanxinzhuang West Road.,Jinan 250022, P.R.China \\ ${ }^{3}$ Advanced Ceramic Institute, Zibo New \& Hi-tech Industrial Development Zone, Zibo 255000, P.R.China
}

\begin{abstract}
With the rapid development of society and the sustainable growth of population, people's demand for water has been increasing continually. In consequence, more and more sludge was generated from purification process in waterworks. Treating and utilizing the sludge efficiently and safely has becoming more and more important. In this paper, the composition and treatment process of sludge from municipal waterworks was introduced firstly.And then the comprehensive utilization of sludge and the problems among the utilization was focused on. New methods for sludge treatment and utilization as resources were explored at last.
\end{abstract}

\section{Introduction}

Every year, about 1.5 billion cubic meters sludge was generated in China's urban water supply plants.If the discharged sludge was treated and utilized improperly, it will have a serious negative impact on the surrounding ecological environment.Therefore, the disposal of sludge from waterworks has become a prominent problem in the field of environmental pollution prevention and control ${ }^{[1]}$. There are many methods for sludge disposal, but the cost of most of them is relatively high, and the impact on the environment is relatively great. Therefore, how to treat and utilize these sludges economically and environmentally has become a hot issue in the field of water treatment.

\section{Composition of sludge in municipal waterworks}

The sludge of municipal waterworks is mainly composed of impurities such as organic matter, inorganic substances, heavy metal elements and the coagulant added during the water treatment process. According to the analysis of the composition of sewage and sludge in some waterworks, the sewage and sludge of the water supply plant almost contain all the elements and compounds of the surface layer through which the raw water flows. Table 1 shows the coagulation sedimentation tanks of four different waterworks. The typical composition of discharged sludge from coagulative precipitation tank was shown in Table $1^{[2]}$.
Table 1. Composition of sludge from coagulative precipitation tank

\begin{tabular}{|c|c|c|c|c|}
\hline \multirow{3}{*}{$\begin{array}{l}\text { Coagulant } \\
\text { name }\end{array}$} & \multicolumn{2}{|c|}{$\begin{array}{c}\mathrm{AI}_{2}\left(\mathrm{SO}_{4}\right)_{3} \cdot 18 \mathrm{H}_{2} \mathrm{O} \\
\text { Coagulant }\end{array}$} & \multicolumn{2}{|c|}{$\begin{array}{c}\mathrm{FeCl}_{3} \cdot 6 \mathrm{H}_{2} \mathrm{O} \\
\text { Coagulant }\end{array}$} \\
\hline & \multicolumn{2}{|c|}{$\begin{array}{l}\text { Percentage of total } \\
\text { sludge }\end{array}$} & \multicolumn{2}{|c|}{$\begin{array}{l}\text { Percentage of total } \\
\text { sludge }\end{array}$} \\
\hline & $\begin{array}{l}\text { A water } \\
\text { works }\end{array}$ & $\begin{array}{l}\text { B water } \\
\text { works }\end{array}$ & $\begin{array}{l}\mathrm{C} \text { water } \\
\text { works }\end{array}$ & $\begin{array}{c}\text { D water } \\
\text { works }\end{array}$ \\
\hline $\mathrm{CaCO}_{3}$ & 27.4 & 33.4 & 43.9 & \\
\hline $\mathrm{SiO}_{2}$ & 42.85 & 17.1 & 26.2 & 33.4 \\
\hline $\mathrm{Fe}_{2} \mathrm{O}_{3}$ & 1.7 & 6.7 & 22.3 & 20.9 \\
\hline $\mathrm{AI}_{2} \mathrm{O}_{3}$ & 9.4 & 44.2 & 6.6 & 0.6 \\
\hline $\mathrm{P}_{2} \mathrm{O}_{5}$ & l & l & 2.6 & / \\
\hline $\mathrm{K}_{2} \mathrm{O}$ & 1.8 & / & 1.2 & / \\
\hline $\mathrm{MgO}$ & 0.5 & 0.85 & 0.79 & 0.48 \\
\hline $\mathrm{SO}_{2}$ & l & l & 0.4 & / \\
\hline $\mathrm{TiO}_{2}$ & l & / & 0.4 & l \\
\hline $\mathrm{Mn}_{2} \mathrm{O}_{3}$ & 0.36 & 3.4 & 0.2 & I \\
\hline $\mathrm{BaO}$ & 0.04 & I & 0.13 & I \\
\hline $\mathrm{Cr}_{2} \mathrm{O}_{3}$ & l & / & 0.05 & / \\
\hline $\mathrm{ZnO}$ & l & l & 0.04 & l \\
\hline \multicolumn{5}{|c|}{ Percentage of total dry weight } \\
\hline $\begin{array}{c}\text { Combustion } \\
\text { loss value }\end{array}$ & 16.6 & 30.1 & 5.7 & 16.4 \\
\hline
\end{tabular}

\section{Typical treatment process of sludge in waterworks}

The typical treatment process of sludge in waterworks was 
shown as Figure 1.

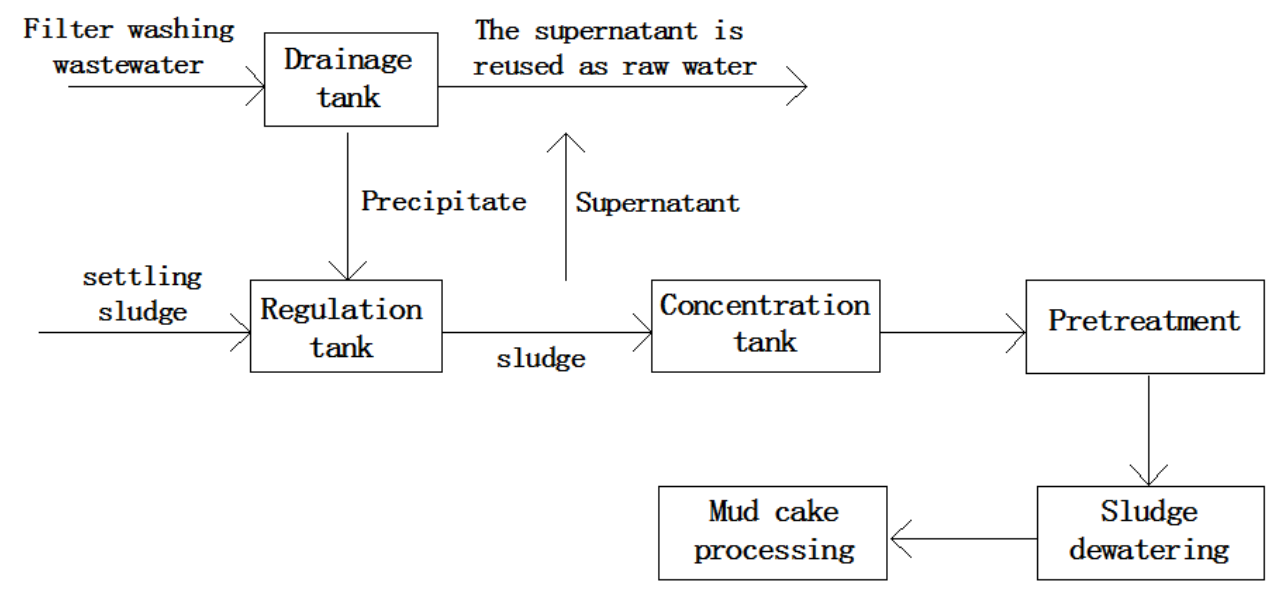

Figure 1 Typical treatment process of sludge in waterworks

\subsection{Regulation}

Both the sedimentation tank drain water and the filter backwash water are intermittently discharged, and the flow rate and mud content vary with time. If it is discharged directly into the concentration tank, the concentration tank is bulky and difficult to manage. In order to make the subsequent equipment load evenly, it is necessary to set a regulating tank for draining mud and backwashing water.

\subsection{Concentration}

Concentration is to reduce the water content of the sludge and reduce the volume of the sludge, thereby reducing the amount of subsequent treatment. The muddy water is usually concentrated in a concentration tank, and the concentration that can be achieved by the mud is determined by the concentration time and concentration conditions. Sludge concentration has methods such as gravity concentration, air flotation concentration, micropore concentration, membrane concentration and biological flotation, and gravity concentration is commonly used.

\subsection{Pretreatment}

The dewatering performance of sludge is usually expressed by specific resistance. The smaller the specific resistance is, the better the dewatering performance of the sludge is. Generally, the specific resistance of the sludge is large, and direct dehydration is difficult. In order to improve sludge dewatering performance, it is often pretreated before sludge is dewatered. The pretreatment of sludge can be divided into physical pretreatment and chemical pretreatment. Physical pretreatment with heat pretreatment and freeze treatment heating can reduce the viscosity coefficient of the liquid, and freezing can separate the water from the solid through the form of ice crystals. Chemical pretreatment includes acid treatment, alkali treatment, and high-molecular flocculant treatment. At present, the most commonly used polymer flocculant (such as polyacrylamide) depends on its type, sludge properties, $\mathrm{pH}$ and concentration.

\subsection{Dewatering}

Sludge dewatering is the key to sludge treatment. By dewatering, the volume of sludge can be greatly reduced. The sludge has a solid content of more than $20 \%$ after dewatering, which is convenient for transportation. Sludge dewatering can be divided into natural drying and mechanical dehydration. Natural dehydration, such as natural drying, low processing cost, low maintenance management costs, but large area, low dehydration efficiency, dry and less climatic conditions, and therefore limited in application. At present, most of the mechanical dewatering is adopted, which has the advantages of small occupied area, large amount of treated mud, high solid content and good adaptability.

The choice of dewatering machinery involves the dewatering characteristics of the sludge, the cost of the project, the operating costs, etc., which need to be determined after comprehensive comparison. For comprehensive performance and cost considerations, pressure filtration and centrifuge are the more rational choice for sludge dewatering.

\section{Comprehensive Utilization of sludge from waterworks}

\subsection{Utilization of sludge from waterworks in sewage treatment}

Basibuyuk et al. ${ }^{[3]}$ studied the use of iron sludge in water purification plants as a coagulant to treat wastewater containing vegetable oil. The results show that iron-containing sludge is used as a coagulant alone. At $\mathrm{pH}=6$ and sludge dosage is $1100 \mathrm{mg} / \mathrm{L}$, the iron-containing sludge is very good for oil, COD and total suspended solids in refinery industrial wastewater. Good removal efficiency; when $1000 \mathrm{mg} / \mathrm{L}$ sludge is used in combination with $12.5 \mathrm{mg} / \mathrm{L}$ ferric chloride, the removal rates of oil, COD and total suspended solids can reach $99 \%, 83 \%$ and 
$99 \%$, respectively. Iron sludge has the same treatment effect as aluminum chloride and is enhanced when used in combination with ferric chloride.

Guan et al. ${ }^{[4]}$ conducted a study on the removal of particulate contaminants from sewage by aluminum sludge in water purification plants. The results show that the addition of aluminum sludge in the primary treatment of sewage can increase the removal rate of suspended solids and COD in sewage. The aluminum hydroxide precipitate in the sludge removes $48-200 \mathrm{mmol}$ of fine particles in the chemical coagulation process, and the optimum sludge dosage is about $18-20 \mathrm{mg} / \mathrm{L}$; increasing the stirring speed or reducing the sludge floc The size can enhance the removal effect of suspended solids and COD. In the process of particle contaminant removal, no charge neutralization is involved. The surface of sewage and aluminum-containing sludge has negative charge, which is mainly combined with flocculation and physical adsorption.

\subsection{Utilization of sludge from waterworks in other fields}

Ren Biao et al. studied the production of fly ash-clay bricks with a volume ratio of $30 \%$ to $45 \%$ and a water content of $60 \%$ to $80 \%$. The performance of the finished products reached the national standard (GB/T5101-98) ${ }^{[5]}$.

The results of the test of the landfill cover material of the sewage plant sludge made by Chen Shaowei et al. prove that the anti-seepage performance of the feed water plant sludge under the operating pressure of the general landfill compaction equipment meets the national standard; the heavy metal content is far lower than the "Contamination Control Standards for Agricultural Sludge" and does not detract from the agricultural value of the landfill after the closure; the pollutants contained in the rainwater penetrating the sludge cover will not be filled. The leachate treatment capacity of the buried field causes impact ${ }^{[6]}$.

The water supply sludge is used in agriculture or gardens. When the application rate is small $\left(20 \mathrm{t} / \mathrm{hm}^{2}\right)$, it will not have a negative impact on crops and the environment. If it is used on special land or in mountainous areas and construction areas, the application rate can be relatively large. Some $\left(20 \mathrm{t} / \mathrm{hm}^{2} \sim 200 \mathrm{t} / \mathrm{hm}^{2}\right)$, but need to strengthen management and monitoring to avoid secondary damage caused by rainwater runoff and leachate.

\subsection{Recovery of metal salts in sludge}

Since the aluminum salt such as aluminum sulfate or polyaluminum chloride is widely used as a coagulant for water treatment in the water supply plant, the aluminum content in the sludge is high, and the aluminum content in the sludge solids is $15 \%$ to $40 \%{ }^{[7]}$. Many scholars have carried out a series of researches on the reuse of sludge or the recovery of aluminum salts. The methods mainly include acidification, alkalization, ion exchange and membrane ${ }^{[8]}$.
Iron salt coagulants are also commonly used in water plants. After use, the iron salt coagulant mixes a large amount of impurities into a precipitate, and recovers the iron salt in the precipitate, which is a problem currently faced by water plants. The use of acid to regenerate iron salts requires the $\mathrm{pH}$ of the settled sludge to be reduced to 1.5 to 2.0. The method uses a large amount of acid, high processing cost and how to further reduce the processing cost, also needs to find a more convenient method.

\subsection{Problems in utilization of sludge from waterworks}

It is a negative method to dispose of the cement cake in the water plant, and the method of making the mud cake into useful articles is positive. However, there are still some problems in the current resource utilization of sludge:

(1) The raw materials for brick making and building materials have certain technical requirements, so the sludge for making products is required to be high. In most cases, a certain amount of additives need to be added to meet the requirements.

(2) When the sewage treatment of sewage from the water supply plant is carried out, the sludge usage is fluctuating due to the unstable nature of the sludge, which brings difficulties to the treatment.

(3) The manufacturing process is complicated and the cost is high.

(4) When a large number of products are produced from the dewatered sludge of the water supply plant, the amount of sludge in the water supply plant is insufficient, and it is impossible to form a scale production, and the price cannot compete with similar products.

\section{Conclusion}

The rational treatment of water supply sludge and the effective use of renewable resources are issues of common concern in all countries of the world. An effective sludge treatment method should take into account environmental and ecological benefits, social benefits and economic benefits. At present, most of the researches on the resource utilization of feed water sludge at home and abroad have remained at the laboratory level, and there have been few reports on large-scale promotion and use. In order to save costs, many water supply plants use simple methods such as landfill to treat feed water sludge, which can also cause unforeseen hazards while wasting resources. In summary, the resource utilization of feed water sludge is the ultimate way to treat water sludge. However, it is necessary to conduct more in-depth research to truly realize the mass resource utilization of water supply sludge and achieve comprehensive utilization.

\section{Acknowledgements}

This work was financially supported by the Shandong Provincial Key Research and Development Program(2016CYJS07A03-2), and partly supported by 
Shandong Provincial Key Research and Development Program(2017GSF17105).

\section{References}

1. Pan Yanqiu. Research on Wastewater Sludge Recovery and Treatment Technology in Water Supply Plant [D]: Dissertation, Chongqing: Northeast Normal University(2009).

2. Jiang Jinhui. Discussion on some problems of sludge treatment in water purification plant [J]. Water supply and drainage technology development, 4:98 99,(1995).

3. Basibuyuk M, Kalat D G. The use of water works sludge for the treatment of vegetable oil refinery industry wastewater [J]. Environ Technol, 25 (3): 373-380,(2004).

4. Guan X H, Chen G H, Shang C. Re-use of water treatment works sludge to enhance particulate pollutant removal from sewage [J]. Water Res, 39(15): 3433-3440, (2005).

5. Ren Bozhi. Experiment of water supply sludge from municipal water supply plant for burning fly ash-clay bricks[J]. Urban Environment and Urban Ecology, (5), (2003).

6. Chen Shaowei et al. Experimental study on sludge from landfill plant as landfill material[J]. Environmental Pollution Control Technology and Equipment, (1),(2002).

7. Parso ns S A, DAN IELS S J. The Use of Recov ered Coag ula nts In Wastewater Treatment [J]. ENV IRON T EC H, (20),(1999).

8. Zhu Zhiping. Study on the Distribution of Hydrolyzed Species in Aluminum Salt Coagulation[J]. China Water \& Wastewater, (4), (1995). 